\section{Interaction of Insects and Weeds in a Snap Bean Agroecosystem}

\author{
Joseph N. Aguyoh and John B. Masiunas ${ }^{1}$ \\ Department of Natural Resources and Environmental Sciences, University of \\ Illinois, 1201 West Gregory Drive, Urbana, IL 61801
}

\section{Catherine Eastman \\ Illinois Natural History Survey, 607 E. Peabody Drive, Champaign, IL 61820}

Additional index words. potato leafhopper, Empoasca fabae, bean leaf beetle, Cerotoma trifurcata, Phaseolus vulgaris, redroot pigweed, Amaranthus retroflexus, large crabgrass, Digitaria sanguinalis

Abstract. Integrated weed management strategies maintain sub-threshold levels of weeds. The remaining weeds may impact the feeding and habitation patterns of both potato leafhoppers and bean leaf beetles in a snap bean agroecosystem. The objective of our study was to determine the effect of interference between snap beans (Phaseolus vulgaris L.) and either redroot pigweed (Amaranthus retroflexus L.) or large crabgrass (Digitaria sanguinalis L.) on populations of potato leafhopper [Empoasca fabae (Harris)] and bean leaf beetle [Cerotoma trifurcata (Forster)]. Plots were seeded with redroot pigweed or large crabgrass at either the same time as snap bean planting (early) or when snap bean had one trifoliate leaf open (late). The weed density averaged two plants per meter of row. Bean leaf beetle populations, snap bean pod damage, and leaf defoliation were lower in weed-free plots compared to those with either early emerging pigweed or crabgrass. Leafhopper nymphs and adults were $31 \%$ to $34 \%$ less in plots with crabgrass emerging with snap beans compared to those in weed-free snap bean plots. Thus, the effect of sub-threshold densities of pigweed and crabgrass on insect pests in snap bean varied depending on the species and should be considered when deciding to integrate weed management approaches.

In agroecosystems, weeds not only compete directly with crops but also influence populations of insect pest and beneficial species. By serving as refugia, providing alternative food sources, or affecting crop attractiveness for pest infestations, weeds can have positive or negative effects on insect damage depending on the dynamics of the specific crop and pest species (Altieri and Letourneau, 1982; Altieri and Whitcomb, 1979; Hammond and Jeffers, 1990; Way and Cammell, 1981). Knowledge of these interactions between weeds and insects can be an important management tool, especially when the crop pest damage can be minimized by modifying the agroecosystem (Oloumi-Sadeghi et al., 1989; Van Wychen et al., 2001).

Snap (green) beans are planted over a 4month period in the midwestern United States and harvested $\approx 2$ months after planting. As a result, they can serve as a trap crop for pests from surrounding field crops [e.g., corn (Zea mays L.), soybeans (Glycine max L.)] that are

Received for publication 8 Nov. 2002. Accepted for publication 18 May 2003. This paper is a portion of a thesis submitted by Joseph N. Aguyoh in partial fulfillment of the requirements for $\mathrm{PhD}$ degree. This research was partially supported by funding from the North Central Region Integrated Pest Management Program. Mention of a trademark, proprietary product, or vendor does not constitute a guarantee or warranty of the product by the Univ. of Illinois or the Illinois Natural History Survey and does not imply its approval to the exclusion of other products or vendors which also may be suitable.

${ }^{1}$ To whom reprint requests should be addressed. E-mail:masiunas@uiuc.edu planted on much larger acreages (Flood et al., 1995). Bean leaf beetles and potato leafhoppers, the most damaging insect pests that attack snap beans in the midwestern United States, can cause severe yield losses if not controlled (Gonzalez and Wyman, 1991; Lindgren and Coyne, 1995; Smelser and Pedigo, 1992).

Adult bean leaf beetles mostly feed on the foliage and pods of snap bean, soybean, and similar legumes. Colonizing adults emerge from overwintering sites in mid-April in Illinois and attack emerging soybean and similar legume seedlings. First- and second-generation adults are present from mid-July through late September (Waldbauer and Kogan, 1976). Feeding by adults on primary and early trifoliate leaves can decrease plant size, vigor, and yield (Flood et al., 1995). Defoliation and pod feeding (clipping or scarring) can reduce pod yield and quality (Smelser and Pedigo, 1992). Damaged pods are predisposed to secondary infection by bacteria and fungi, which may cause rotting and discoloration. Hunt et al. (1994) reported that leaf defoliation of 68\% applied to seedling soybean to simulate bean leaf beetle injury caused a $12 \%$ reduction in yield. Witkowski and Echtenkamp (1996) found that bean leaf beetle feeding caused $\approx 25 \%$ to $40 \%$ soybean pod damage, depending on planting date. As a food crop, snap beans have a lower tolerance level for injury than do field crops such as soybean (Flood et al., 1995).

The potato leafhopper is a generalist feeder of many legumes. Leafhoppers, in feeding on plant juices, produce the characteristic "hopperburn" plant injury, caused by phloem necrosis and blockage of photosynthate transport
(Nielsen et al., 1990) that results from multiplecell laceration during very short probes by the leafhoppers on veins or stems (Calderon and Backus, 1992). Symptoms of hopperburn include leaf curling and a triangular yellowing or browning of the leaf tips. Plants become stunted and have smaller root systems, with subsequent reductions in bean yield and quality. Seedling plants are at greatest risk (Flood et al., 1995). Most research on hopperburn effects on crop yield and quality has concentrated mainly on alfalfa (Medicago sativa $\mathrm{L}$.) and soybean, with limited research on snap beans. But planting date and cultivar may determine how potato leafhopper injury effects bean yield. Gonzalez and Wyman (1991) found that potato leafhoppers caused a yield reduction in snap bean of $54 \%$ to $67 \%$ in early plantings and $9 \%$ to $32 \%$ in late plantings. Lindgren and Coyne (1995) identified significant differences in leafhopper injury and yield among 22 cultivars or lines of dry beans.

Some information is available on insectweed interactions of bean leaf beetle and potato leafhopper. Bean leaf beetles will feed on wild species of the legumes Amphicarpa, Desmodium, Lespedeza, and Stophostyles as well as a very few species of the non-legumes Urtica, Laportea, and Euonymous, but no other broadleaf species or grasses (Helm et al., 1983; Kogan et al., 1980; Zeiss and Pedigo, 1996). Several broadleaf weed species, but not grasses, are suitable hosts for potato leafhopper (Lamp et al., 1984, 1994; Poos and Wheeler, 1943). When alfalfa was intercropped with smooth bromegrass (Bromus inermis Leyss) and orchardgrass (Dactylis glomerata L.), biomass loss was 0 to $35 \%$ of the biomass loss in the alfalfa monoculture (DeGooyer et al., 1999). The reduction in the number of potato leafhoppers in grassy weeds has been attributed to the negative reaction of potato leafhoppers to the stimuli obtained from physical contact with the grass (Roda et al., 1997b).

No studies have been conducted on the interaction of potato leafhoppers or bean leaf beetles with weeds in snap bean cropping systems. We selected redroot pigweed and large crabgrass, two of the most common weeds found in snap bean fields in the Midwest, for experiments to determine weed economic thresholds (Aguyoh and Masiunas, 2003a, 2003b) and impact on insect pest problems. Our objectives in this study were to determine the influence of redroot pigweed and large crabgrass on population densities of bean leaf beetles and potato leafhoppers as well as the feeding of these insects on snap beans.

\section{Materials and Methods}

Field experiments were conducted in 1998 and 1999 at the Univ. of Illinois Cruise Tract Vegetable Research Farm in Champaign. The soil type was a Flanagan silt loam (fine montmorillonitic, mesic, Aquic Argiudoll; pH 6.5 and organic matter of $3.2 \%$ ). Site preparation in both years consisted of fall chisel plowing followed by spring disking and harrowing. The experiment was a split-plot arrangement of a randomized complete-block design with 
four replications. Treatments included whole plots as weed planting dates (no weeds, early pigweed or crabgrass, late pigweed or crabgrass) and subplots were four weed densities $(0.5,1,2$, or 8 pigweed or crabgrass per meter of row), with a whole-plot average of 2 weeds per meter of row. Whole plots were $36 \times 6 \mathrm{~m}$, and subplots were $9 \times 6 \mathrm{~m}$. Each plot contained eight rows of snap beans with a row spacing of $90 \mathrm{~cm}$. A 3-m area of bare ground separated the whole-plot treatments.

'Matador' snap bean seeds were planted at $80 \mathrm{~kg} \cdot \mathrm{ha}^{-1}$ to give a plant population of 116,000 plants/ha on 1 June 1998 and 28 May 1999. One set of the plots was seeded with redroot pigweed or large crabgrass at snap bean planting (early), and the second set of plots was seeded $\approx 10 \mathrm{~d}$ later, when the first trifoliate leaves of snap bean were opening (10 June 1998 and 8 June 1999) (late). Redroot pigweed and large crabgrass seeds were purchased from a commercial supplier (Valley Seed Co., Fresno, Calif.) and hand-seeded in clumps adjacent to the crop row. Early pigweed or crabgrass emerged along with snap beans within 6 to 8 $\mathrm{d}$ of planting depending on the year, while late pigweed and crabgrass emerged within 3 to $4 \mathrm{~d}$ after seeding. To maintain the designated weed densities, the seedlings were thinned by hand at the 2- to 4-leaf stage.

Annual grass weeds in pigweed plots were controlled by postemergence applications of sethoxydim \{2-[1-(ethoxyimino) butyl]-5-[2(ethylthio) propyl]-3-hydroxy-2-cyclohexene1 -one at the rate of $0.21 \mathrm{~kg} \cdot \mathrm{ha}^{-1}$ a.i. $\approx 2$ weeks after snap bean emergence. In crabgrass plots, most annual broadleaf weeds were controlled by a postemergence application of bentazon [2-(1-methylethyl)-(1H)-2,1,3-benzothiadiazin-4(3H)-one 2,2-dioxide] at $1.1 \mathrm{~kg} \cdot \mathrm{ha}^{-1}$ a.i. $\approx 2$ weeks after snap bean emergence. Any weeds remaining after herbicide application were controlled by subsequent cultivation and hoeing.

Potato leafhopper nymph sampling was done on 24 June 1999 by direct observation and counting of the nymphs on $30 \mathrm{~cm}$ of row from the inner two rows of snap beans. At the same time snap bean leaves were also observed for any signs of feeding damage by bean leaf beetles and for "hopperburn" by potato leafhoppers. No direct observation of plants for nymphs was done at 3 weeks after emergence in 1998 because of the wet soils caused by heavy precipitation soon after snap bean emergence. Sweep-net sampling for bean leaf beetle and potato leafhopper was done on 2 and 14 July (24 and 36 d after snap bean emergence) in 1998, and 7 and 11 July (35 and 39 d after emergence) in 1999 , prior to snap bean bloom. Fifty sweeps were made on the second and third rows of snap beans using a $38-\mathrm{cm}$-diameter sweep net. Each forward or backward stroke along the row counted as a sweep. The sweep-net samples were placed in labeled plastic bags and returned to the laboratory for determination of insect counts.

Every 2 weeks, shoots of eight snap bean plants from the third and seventh rows of the plots were cut at soil level and their fresh mass determined. Leaf number per plant was recorded and the shoots were then dried at 70 ${ }^{\circ} \mathrm{C}$ to a constant weight for dry mass (biomass) determination. Crop yield was measured by harvesting snap beans in a 2-m section from each of the two center rows at three harvest dates $\approx 4 \mathrm{~d}$ apart. On each date only snap beans that were marketable $(>5.5 \mathrm{~cm}$ long) were harvested. Total pod weight was determined by summing up the three harvests.

Bean leaf beetle damage to foliage and pods was determined at the first harvest. Feeding on snap bean pods was evaluated by a procedure adapted from Masiunas et al. (1997). A total of 100 pods were sampled from each of the two center rows of each plot, and pod damage was rated on a scale of 0 (no damage) to 4 (one or more deep feeding areas on the pod with at least the seed cavity exposed). The individual ratings of pod damage ratings were summed and converted into an overall percentage. Percent leaf defoliation was determined by counting the number of holes caused by bean leaf beetles on 10 randomly picked trifoliate leaves from 10 snap bean plants in the two center rows. The mean percent defoliation per leaf and total number of leaves per plant were used to determine total leaf defoliation per plant.

Data from each trial were analyzed using the GLM procedure of SAS (SAS Institute, 1998). Percent data were transformed using an arcsine square root transformation before analysis (Steel et al., 1997). Because of the small subplot size (weed density), insect samples were collected from the subplots but averaged for each whole-plot treatment (weed species and planting date) for data analysis. For treatments significant at $P \leq 0.05$, treatment means were separated using Fisher's protected least significant difference procedure (Steel et al., 1997). Untransformed data are presented in the tables.

\section{Results and Discussion}

The precipitation from early June through the first week of August was different during the 1998 and 1999 growing seasons. Higher precipitation was received within 6 weeks of snap bean planting in 1998 compared to 1999 ( 4.1 and $2.6 \mathrm{~cm}$, respectively) (Table 1 ). The temperature was 5 to $7^{\circ} \mathrm{C}$ cooler within the first 2 weeks after planting in 1998 than in 1999. The cooler temperatures might have contributed to the 2 -d delay ( 7 vs. 5 d) in the emergence of snap bean in 1998. Pigweed was more competitive in 1999, when precipitation was low and temperatures were high. Because of persistent rainfall in 1998 during planting, establishment of weed densities was delayed and could have affected early distribution of insects.

Bean leaf beetle populations in the first sweep-net sampling ( 24 or $35 \mathrm{~d}$ after snap bean emergence) were similar in all plots and were not affected by the presence of crabgrass or pigweed in either year (Table 2). In the second sampling (36 or $39 \mathrm{~d}$ after snap bean emergence), however, more bean leaf beetles were collected in plots containing early emerging pigweed or crabgrass compared to the weed-free plots. The greatest number of bean leaf beetles in sweep-net samples was 3.8 beetles per 50 sweeps in the plots with early emerging crabgrass in 1998, and 5.3 beetles per 50 sweeps in the plots with early emerging pigweed in 1999. Percent pod damage ranged from $13 \%$ to $24 \%$ in 1998 and $13 \%$ to $26 \%$ in 1999 depending on weed type and emergence time (Table 2). Snap beans in the early emerging crabgrass plots had greater pod damage in both years (24\% in 1998 and $26 \%$ in 1999) than in the weed-free plots. Leaf defoliation in 1998 was also higher in plots with early emerging crabgrass and pigweeds (15\% and $13 \%$ defoliation, respectively) compared to defoliation levels in the weed-free plots (Table 2). In 1999, defoliation was significantly higher in the early-emerging crabgrass plots ( $15 \%$ defoliation) only when compared to the weed-free plots.

The greater numbers of bean leaf beetle adults and their greater feeding injury to leaves and pods in weedy snap bean plots, may reflect habitat preference of the beetles. Bean leaf beetles feed almost entirely on legumes and do not feed on grasses or pigweed (Helm et al., 1983; Kogan et al., 1980; Zeiss and Pedigo, 1996). The mat-like growth habit of crabgrass shaded the soil near the rows of snap bean and may have increased soil moisture. Masiunas et al. (1997) observed that snap bean pod damage (primarily from bean leaf beetle) was greater in plots planted in killed cereal rye residue or with perennial rye living mulch than in clear-tilled plots. Smith et al. (1988) reported greater numbers of bean leaf beetles in soybean planted in rye no-till plots compared to other treatments because of higher soil moisture in the rye no-till plots. Female bean leaf beetles prefer to oviposit in moist soil (Marrone and Stinner, 1983). Other studies involving tillage or herbicide treatments do not show a consistent pattern with regard to weed management factors affecting bean leaf beetle populations (Buckelew etal., 2000; Buntin etal., 1995; Lam and Pedigo, 1998;Troxclair and Boethel, 1984). Troxclair and Boethel (1984) speculated that differences in early-season soil moisture might make no-till plots more attractive to colonizing beetles but that greater populations of carabid predators in no-till (House and Stinner, 1983) might reduce the size of the emerging firstgeneration beetle population.

Bean leaf beetle numbers in our samples were low (maximum of 5.3 per 50 sweeps), but

Table 1. Mean temperatures ${ }^{z}$ and weekly rainfall and irrigation in 1998 and 1999 at Champaign, Ill.

\begin{tabular}{lccccc}
\hline $\begin{array}{l}\text { Weeks } \\
\text { after planting }^{y}\end{array}$ & \multicolumn{2}{c}{ Temp $\left({ }^{\circ} \mathrm{C}\right)$} & & \multicolumn{2}{c}{ Moisture $(\mathrm{cm})$} \\
\cline { 2 - 3 } \cline { 5 - 6 } & 1998 & 1999 & & 1998 & 1999 \\
\hline 1 & 16 & 21 & & 0.3 & 0.5 \\
2 & 19 & 26 & & 1.6 & 0.3 \\
3 & 22 & 20 & & 0.7 & 1.1 \\
4 & 19 & 21 & & $0.8^{y}$ & $0.7^{y}$ \\
5 & 24 & 23 & & 0.5 & 0.3 \\
6 & 24 & 26 & & 4.5 & $3.4^{y}$ \\
7 & 23 & 22 & & 0.0 & 0 \\
8 & 26 & 27 & & 0.4 & 0.6 \\
9 & 21 & 27 & & 0.2 & 0.7 \\
\hline
\end{tabular}

${ }^{\mathrm{z}}$ Temperature and moisture data were averaged over $7 \mathrm{~d}$ from the date of snap bean planting.

${ }^{\mathrm{y}}$ Indicates weeks the experiment was irrigated. 
pod damage was as high as $24 \%$ to $27 \%$. Flood et al. (1995) advised control of leaf-feeding beetles on snap bean if populations exceeded one beetle per $30 \mathrm{~cm}$ of row or defoliation exceeded 50\%. In Illinois, Weinzierl (2002) recommended controlling even light infestations of bean leaf beetles on snap bean after pod formation to prevent any cosmetic damage from feeding scars. Our sweep-net samples were taken before mid-July, prior to snap bean bloom. First-generation bean leaf beetle adults begin emerging around early to mid-July in Illinois and are present through late August or early September (Waldbauer and Kogan, 1976). Our last sampling may have missed the peak of this generation, which would have produced pod injury.

Direct counts of potato leafhopper nymphs and adults $16 \mathrm{~d}$ after snap bean emergence in 1999 ranged from 0.9 to 1.2 nymphs or 4 to 4.7 adults per meter and were not significantly different among treatments (data not shown). No similar counts were made in 1998. Potato leafhopper nymph populations in the first sweep-net samples at 24 or $35 \mathrm{~d}$ after snap bean emergence ranged from 3.1 to 5.2 nymphs per 50 sweeps depending on weed type, time of weed emergence, and year (Table 3 ). In both years, nymphs were more numerous in weedfree snap bean plots than in plots with early emerging crabgrass. The presence of weeds had no effect on numbers of potato leafhopper adults in the first sweep-net samples in both years (Table 3 ). As the cropping season progressed leafhopper populations increased substantially. In the second sweep-net sampling at $36 \mathrm{~d}$ after snap bean emergence, the populations in 1998 ranged from 32.6 to 49.2 adults per 50 sweeps while in 1999 at $39 \mathrm{~d}$ after snap bean emergence they ranged from 62.9 to 90.6 adults per 50 sweeps. The snap bean plots with early emerging crabgrass had fewer adults compared to counts in weed-free plots. Flood et al. (1995) advised controlling potato leafhoppers when populations of 0.5 leafhoppers per sweep ( 25 leafhoppers per 50 sweeps) were present in seedling green beans or one leafhopper per sweep (50 leafhoppers per 50 sweeps) when beans were in the third trifoliate to bud stage. Extension recommendations for management of potato leafhopper on snap beans in Illinois suggest insecticide applications if populations exceed one adult per sweep or one nymph per 10 leaves (Weinzierl, 2002) In 1999, leafhoppers in all treatments of our study exceeded this threshold and insecticide application would have been warranted, but in 1998 only the population in the weed-free plots met thresholds.

We observed $\approx 1.5$ times as many leafhoppers in weed-free snap bean plots compared to those in plots with crabgrass. Our results show a similar trend to other research that has reported reductions in potato leafhopper populations in grass-legume cropping systems (Hammond and Jeffers, 1990; Oloumi-Sadeghi et al., 1989; Roda et al., 1997a, 1997b; Roltsch and Gage, 1990). In contrast, potato leafhopper numbers in plots with pigweed were not significantly different from those in plots with crabgrass and only once were different from numbers in

Table 2. The influence of seeding time of large crabgrass and redroot pigweed on the mean number of bean leaf beetles per 50 sweep net samples at 24 and 36 (1998) or 35 and 39 (1999) days after crop emergence (emerg.) and percent leaf defoliation (defol.) and percent pod damage at first snap bean harvest.

\begin{tabular}{|c|c|c|c|c|c|c|c|c|c|}
\hline \multirow[b]{2}{*}{$\begin{array}{l}\text { Weed } \\
\text { type }\end{array}$} & \multirow[b]{2}{*}{$\begin{array}{l}\text { Time of } \\
\text { emerg. }\end{array}$} & \multicolumn{4}{|c|}{1998} & \multicolumn{4}{|c|}{1999} \\
\hline & & $24 \mathrm{~d}$ & $36 \mathrm{~d}$ & $\begin{array}{l}\text { Leaf } \\
\text { defol. }\end{array}$ & $\begin{array}{c}\text { Pod } \\
\text { damage }\end{array}$ & $35 \mathrm{~d}$ & $39 \mathrm{~d}$ & $\begin{array}{l}\text { Leaf } \\
\text { defol. }\end{array}$ & $\begin{array}{c}\text { Pod } \\
\text { damage }\end{array}$ \\
\hline No weeds & --- & $1.9^{y}$ & $1.6 \mathrm{a}$ & $9 \mathrm{c}$ & $13 \mathrm{a}$ & 1.4 & $3.0 \mathrm{a}$ & $10 \mathrm{a}$ & $14 \mathrm{a}$ \\
\hline Crabgrass & Early & 1.8 & $3.8 \mathrm{c}$ & $15 \mathrm{a}$ & $24 \mathrm{~b}$ & 1.1 & $4.9 \mathrm{bc}$ & $15 \mathrm{~b}$ & $26 \mathrm{~b}$ \\
\hline Crabgrass & Late & 1.9 & $2.3 \mathrm{ab}$ & $13 \mathrm{a}$ & $16 \mathrm{a}$ & 1.2 & $4.6 \mathrm{abc}$ & $11 \mathrm{ab}$ & $13 \mathrm{a}$ \\
\hline Pigweed & Early & 2.1 & $3.1 \mathrm{bc}$ & $15 \mathrm{a}$ & $17 \mathrm{ab}$ & 1.6 & $5.3 \mathrm{c}$ & $11 \mathrm{ab}$ & $14 \mathrm{a}$ \\
\hline Pigweed & Late & 2.0 & $2.0 \mathrm{ab}$ & $12 \mathrm{a}$ & $14 \mathrm{a}$ & 2.8 & $3.3 \mathrm{ab}$ & $11 a b$ & $13 \mathrm{a}$ \\
\hline
\end{tabular}

${ }^{\mathrm{z}}$ Emergence of crabgrass and pigweed was either with the snap beans (early), or at the first trifoliate stage (late) of the snap beans.

y Mean separation in columns by Fisher's protected least significant difference test at $P \leq 0.05$.

Table 3. Influence of emergence time of large crabgrass and redroot pigweed on populations of potato leafhopper nymphs and adults in 50 sweep net samples at 24 to $39 \mathrm{~d}$ after snap bean emergence.

\begin{tabular}{|c|c|c|c|c|c|c|c|}
\hline \multirow{3}{*}{$\begin{array}{l}\text { Weed } \\
\text { type }\end{array}$} & \multirow{3}{*}{$\begin{array}{c}\text { Time of } \\
\text { emergence }^{\mathrm{z}}\end{array}$} & \multicolumn{2}{|c|}{ Leafhopper nymphs } & \multicolumn{4}{|c|}{ Leafhopper adults } \\
\hline & & 1998 & 1999 & \multicolumn{2}{|c|}{1998} & \multicolumn{2}{|c|}{1999} \\
\hline & & $24 \mathrm{~d}$ & $24 \mathrm{~d}$ & $24 \mathrm{~d}$ & $36 \mathrm{~d}$ & $35 \mathrm{~d}$ & $39 \mathrm{~d}$ \\
\hline No weeds & --- & $4.2 b^{y}$ & $5.2 \mathrm{~b}$ & 7.4 & $49.2 \mathrm{c}$ & 9.5 & $90.8 \mathrm{~b}$ \\
\hline Crabgrass & Early & $2.5 \mathrm{a}$ & $4.0 \mathrm{a}$ & 5.4 & $32.6 \mathrm{a}$ & 8.1 & $62.9 \mathrm{a}$ \\
\hline Crabgrass & Late & $3.3 \mathrm{ab}$ & $4.5 \mathrm{ab}$ & 6.2 & $41.2 \mathrm{abc}$ & 9.4 & $70.3 \mathrm{ab}$ \\
\hline Pigweed & Early & $3.2 \mathrm{ab}$ & $4.2 \mathrm{ab}$ & 6.6 & $40.2 \mathrm{abc}$ & 7.8 & $77.4 \mathrm{ab}$ \\
\hline Pigweed & Late & $3.1 \mathrm{ab}$ & $4.7 \mathrm{ab}$ & 7.5 & $37.6 \mathrm{ab}$ & 9.2 & $74.3 \mathrm{ab}$ \\
\hline
\end{tabular}

${ }^{2}$ Emergence of crabgrass and pigweed was either with the snap beans (early), or at the first trifoliate stage (late) of snap beans.

y Mean separation in columns by Fisher's protected least significant difference test at $P \leq 0.05$.

Table 4. Changes in snap bean shoot biomass, yield, pod size, and pod number as influenced by emergence time of large crabgrass and redroot pigweed relative to snap bean emergence. The data are averaged over years.

\begin{tabular}{|c|c|c|c|c|c|c|}
\hline \multirow{2}{*}{$\begin{array}{l}\text { Weed } \\
\text { type }\end{array}$} & \multirow{2}{*}{$\begin{array}{c}\text { Time of } \\
\text { emergence }^{z}\end{array}$} & \multicolumn{2}{|c|}{$\begin{array}{c}\text { Shoot } \\
\text { biomass } \\
\text { (g/plant) }\end{array}$} & \multirow{2}{*}{$\begin{array}{l}\text { Pod } \\
\text { diam } \\
(\mathrm{cm})\end{array}$} & \multirow{2}{*}{$\begin{array}{c}\text { No. of } \\
\text { pods } \\
\text { (no./plant) }\end{array}$} & \multirow{2}{*}{$\begin{array}{c}\text { Yield } \\
\left(\mathrm{t} \cdot \mathrm{ha}^{-1}\right)\end{array}$} \\
\hline & & 1998 & 1999 & & & \\
\hline No weeds & --- & $6.9 b^{y}$ & $5.8 \mathrm{~b}$ & $0.68 \mathrm{c}$ & 6.2 & $2.5 \mathrm{~b}$ \\
\hline Crabgrass & Early & $5.2 \mathrm{a}$ & $5.1 \mathrm{ab}$ & $0.63 \mathrm{ab}$ & 4.7 & $1.6 \mathrm{a}$ \\
\hline Crabgrass & Late & $6.6 \mathrm{~b}$ & $5.5 \mathrm{ab}$ & $0.67 \mathrm{c}$ & 4.5 & $1.7 \mathrm{a}$ \\
\hline Pigweed & Early & $6.4 \mathrm{ab}$ & $4.8 \mathrm{a}$ & $0.62 \mathrm{a}$ & 5.4 & $1.8 \mathrm{ab}$ \\
\hline Pigweed & Late & $6.6 \mathrm{~b}$ & $5.8 \mathrm{~b}$ & $0.66 \mathrm{bc}$ & 5.3 & $2.1 \mathrm{ab}$ \\
\hline
\end{tabular}

${ }^{\mathrm{z} E m e r g e n c e ~ o f ~ c r a b g r a s s ~ a n d ~ p i g w e e d ~ w a s ~ e i t h e r ~ w i t h ~ t h e ~ s n a p ~ b e a n s ~(e a r l y), ~ o r ~ a ~}$ the first trifoliate stage (late) of the snap beans.

${ }^{y}$ Mean separation in columns by Fisher's protected least significant difference test at $P \leq 0.05$

weed-free plots. Lamp et al. (1994) reported that pigweed and four other broadleaves were suitable hosts for potato leafhopper nymphal development and adult oviposition, but that crabgrass was among the least suitable hosts for this insect. The emigration of potato leafhoppers from grassy plots has been attributed to the physical contact between the grass and leafhoppers (Roda et al., 1997b; Roltsch and Gage, 1990). The potential of reducing potato leafhopper damage to a crop through the use of plant diversification is well documented (Barnes and Shaeffer, 1985; DeGooyer et al., 1999; Hammond and Jeffers, 1990; Hutchins and Pedigo, 1989; Lamp, 1991; Lefko et al., 2000; Roda et al., 1997a, 1997b). However, the reduction in snap bean damage may not be great enough to warrant fewer insecticide applications.

Snap bean biomass was different for each year of study and depended on the weed species and their emergence time (Table 4). In both years, late emerging weeds did not affect snap bean biomass, but depending on the year, either early emerging pigweed or early emerging crabgrass reduced snap bean biomass compared to the weed-free control. In 1998, early emerging crabgrass reduced snap bean biomass by $25 \%$ compared to the control. In 1999, however, early emerging pigweed reduced snap bean biomass by $17 \%$ compared to the control. The presence of a greater number of bean leaf beetles in weedy and leafhoppers in weed-free snap bean plots, had no effect on snap bean biomass [correlation coefficient $(r)$ only 0.14 in 1998 and 0.32 in 1999].

The yield of snap bean and yield parameters pod diameter and pod number were not affected by the year, but pod diameter was dependent on time of weed emergence (Table 4). Yield was greater in the weed-free snap bean plots compared to plots containing crabgrass. The lower yields in crabgrass plots might be attributed to competition between these weeds and snap beans. The level of pod damage and greater defoliation of snap beans in the early emerging crabgrass plots may also have contributed to lower yields. There were no differences in snap bean yields between the early or late emerging pigweed plots and weed-free control. The average snap bean yield of $2 \mathrm{t} \cdot \mathrm{ha}^{-1}$ over 2 years from our experiment was lower than the 
national average snap bean yield of $7.7 \mathrm{t} \cdot \mathrm{ha}^{-1}$ (Maynard and Hochmuth, 1997).

Snap bean pod diameter was dependent on the time of weed emergence. Snap beans from weed-free plots and late emerging crabgrass or pigweed plots were larger than those from early emerging pigweed or crabgrass plots (Table 4). The reduction in the snap bean pod diameter in early emerging weed plots is most likely attributable to weed interference. The number of snap bean pods per plant was statistically similar in all the plots, although there was an average of 1 to 1.5 fewer pods per plant in plots with weeds.

Most snap bean growth parameters were not correlated with either leafhopper or bean leaf beetle populations, based on our sampling data. For example, correlation coefficient $(r)$ for the insect pest population and snap bean yield was 0.18 and 0.40 for leafhoppers and bean leaf beetles, respectively. The reductions in the growth and yield of snap beans we observed were in early emerging crabgrass or pigweed plots, and may be attributed mainly to the competition of the two weeds.

Our study indicates that the presence of weeds in snap bean early season can affect populations of potato leafhoppers and bean leaf beetles, and that these insects respond differently to the presence of crabgrass. Crabgrass emerging early with snap bean tends to reduce potato leafhopper populations but attract a greater number of bean leaf beetles. The effects of pigweed on leafhoppers was not noticeable, but significantly more bean leaf beetles were found in snap bean plots with early emerging pigweed than in weed-free plots. Weed interference had a greater influence on snap bean yield than did the leafhopper and beetle populations encountered in our study.

Based on our results, snap bean pod damage and leaf defoliation by bean leaf beetle should be closely monitored in the presence of crabgrass. An understanding of the feeding and population distribution of potato leafhoppers and bean leaf beetles in a snap bean-weed agroecosystem may allow management systems to be developed specifically for these pests in the presence of sub-threshold densities of weeds.

\section{Literature Cited}

Aguyoh, J.N. and J.B. Masiunas. 2003a. Interference of redroot pigweed (Amaranthus retroflexus $\mathrm{L}$.) with snap beans (Phaseolus vulgaris L.). Weed Sci. 51. (In press.)

Aguyoh, J.N. and J.B. Masiunas. 2003b. Interference of large crabgrass (Digitaria sanguinalis L.) with snap beans (Phaseolus vulgaris L.). Weed Sci. 51. (In press.)

Altieri, M.A. and D.K. Letourneau. 1982. Vegetation management and biological control in agroecosystems. Crop Protection 1:405-430.

Altieri, M.A. and W.H. Whitcomb. 1979. The potential use of weeds in the manipulation of beneficial insects. HortScience 14:12-18.

Barnes, D.K. and C.C. Shaeffer. 1985. Alfalfa, p. 89-97. In: M.E. Heath, D.F. Barnes, and D.S. Metcalfe (eds.). Forages: The science of grassland agriculture. Iowa State Univ. Press, Ames.

Buckelew, L.D., L.P. Pedigo, H.M. Mero, M.D.K. Owen, and G.L. Tylka. 2000. Effects of weed management systems on canopy insects in herbicide-resistant soybeans. J. Econ. Entomol. 93:1437-1443.

Buntin, G.D., W.L. Hargrove, and D.V. McCracken. 1995. Population of foliage-inhabiting arthropods on soybean with reduced tillage and herbicide use. Agron. J. 87:789-794.

Calderon, J.D. and E.A. Backus 1992. Comparison of the probing behaviors of Empoasca fabae and E. kraemeri (Homoptera: Cicadellidae) on resistant and susceptible cultivars of common beans. J. Econ. Entomol. 85:88-99.

DeGooyer, T.A., L.P. Pedigo, and M.E. Rice. 1999. Effect of alfalfa-grass intercrops on insect populations. Environ. Entomol. 28:703-710.

Flood, B., G. Hein, and R. Weinzierl. 1995. Beans, p. 41-54. In: R. Foster and B. Flood (eds.). Vegetable pest management. Meister Publ. Co., Willoughby, Ohio.

Gonzalez, A.L. and J.A. Wyman. 1991. Effect of varying potato leafhopper (Homoptera: Cicadellidae) population densities on snap bean yield. J. Econ. Entomol. 84:644-649.

Hammond, R.B. and D.L. Jeffers. 1990. Potato leafhopper (Homoptera: Cicadellidae) populations on soybean relay intercropped into winter wheat. Environ. Entomol. 19:1810-1819.

Helm, C.G., M.R. Jeffords, S.L. Post, and M. Kogan. 1983. Spring feeding of overwintered bean leaf beetles (Coleoptera: Chrysomelidae) on nonleguminous hosts. Environ. Entomol. $12: 321-322$.

House, G.S. and B.R. Stinner. 1983. Arthropods in no-tillage soybean agroecosystems: community composition and ecosystem interactions. Environ. Mgt. 7:23-28.

Hunt, T.E., L.G. Higley, and J.F. Witkowski. 1994. Soybean growth and yield after simulated bean leaf beetle injury to seedlings. Agron. J. 86:140-146.

Hutchins, S.H. and L.P. Pedigo. 1989. Potato leafhopper induced injury on growth and development of alfalfa. Crop Sci. 29:1005-1011.

Kogan, M., G.P. Waldbauer, G. Boiteau, and C.E. Eastman. 1980. Sampling bean leaf beetles on soybean, p. 210-236. In: M. Kogan and D.C. Herzog (eds.). Sampling methods in soybean entomology. Springer-Verlag, New York.

Lam, W.F. and L.P. Pedigo. 1998. Response of soybean insect communities to row width and crop-residue management systems. Environ. Entomol. 27:1069-1079.

Lamp, W.O. 1991. Reduced Empoasca fabae (Homoptera: Cicadellidae) density in oatalfalfa intercrop systems. Environ. Entomol. 20:118-126

Lamp, W.O., M.J. Morris, and E.J. Armbrust. 1984. Suitability of common weed species as host plants for the potato leafhopper, Empoasca fabae. Entomol. Expt. Appl. 36:125-131.

Lamp, W.O., G.R. Nielsen, and S.D. Danielson. 1994. Patterns among host plants of potato leafhopper, Empoasca fabae (Homoptera: Cicadellidae). J. Kansas Entomol. Soc. 67:354-368.

Lefko, S.A., L.A. Pedigo, and M.E. Rice. 2000. Alfalfa stand tolerance to potato leafhopper and its effect to economic injury level. Agron. J. 92:726-732.

Lindgren, D.T. and D.P. Coyne. 1995. Injury and yield of leafhopper-infested dry beans. J. Amer. Soc. Hort. Sci. 120:839-842.

Marrone, P.G. and R.E. Stinner. 1983. Effects of soil moisture and texture on oviposition preference of the bean leaf beetle, Cerotoma trifurcata (Fortser) (Coleoptera: Coccinellidae). Environ. Entomol. 12:426-428.

Masiunas, J.B., D.M. Eastburn, V.N. Mwaja, and C.E. Eastman. 1997. The impact of living and cover crop mulch systems on pests and yield of snap beans and cabbage. J. Sustainable Agr. 9:61-88.

Maynard, D.N. and G.J. Hochmuth. 1997. Knott's handbook for vegetable growers. Wiley, New York.

Nielsen, G.H., W.O. Lamp, and G.W. Stutte. 1990. Potato leafhopper (Homoptera: Cicadellidae) feeding disruption on phloem translocation in alfalfa. J. Econ. Entomol. 83:807-813.

Oloumi-Sadeghi, H., L.R. Zavaleta, G. Kapusta, W.O. Lamp, and E.J. Armbrust. 1989. Effect of potato leafhopper (Homoptera: Cicadellidae) and weed control on alfalfa yield and quality. J. Econ. Entomol. 82:923-923.

Poos, F.W. and N.H. Wheeler. 1943. Studies on host plants of the leafhoppers of the genus Empoasca. USD. Tech. Bul. No. 850.

Roda, A.L., D.A. Landis, and M.L. Coggins. 1997a. Forage grasses elicit emigration of adult potato leafhopper (Homoptera: Cicadellidae) from alfalfa-grass mixtures. Environ. Entomol. 26:745-753.

Roda, A.L., D.A. Landis, and J.R. Miller. 1997b. Contact induced emigration of potato leafhopper (Homoptera: Cicadellidae) from alfalfaforage grass mixtures. Environ. Entomol. 26:754-762.

Roltsch, W.J. and S.H. Gage. 1990. Potato leafhopper (Homoptera: Cicadellidae) movement, oviposition, and feeding response patterns in relation to host and nonhost vegetation. Environ. Entomol. 19:524-533.

SAS Institute. 1998. SAS/STAT user's guide. Release 7.00. SAS Inst., Cary, N.C.

Smelser, R.B. and L.P. Pedigo. 1992. Bean leaf beetle (Coleoptera: Chrysomelidae) herbivory on leaf, stem, and pod components of soybean. J. Econ. Entomol. 85:2408-2412.

Smith, A.W., R.B. Hammond, and B.R. Stinner. 1988. Influence of rye cover crop management on soybean foliage arthropods. Environ. Entomol. 17:109-114.

Steel, R.G.D., J.H. Torrie, and D.A. Dickey. 1997. Principles and procedures of statistics: A biometrical approach. 3rd ed. McGraw Hill, New York.

Troxclair, N.N. and D.J. Boethel. 1984. Influence of tillage practices and row spacing on soybean insect populations in Louisiana. J. Econ. Entomol. 77:1571-1579.

Van Wychen, L.R., R.G. Harvey, and J.L. Wedberg. 2001. Interactions among weed, insect, and common rust treatments in sweet corn. Weed Sci. 49:209-216.

Waldbauer, G.P. and M. Kogan. 1976. Bean leaf beetle (Cerotoma trifurcata): Phenological relationship with soybean in Illinois. Environ. Entomol. 5:3544.

Way, M.J. and M.E. Cammell. 1981. Effects of weeds and weed control on invertebrate pest ecology, p. 443-458. In: J.M. Thresh (ed.). Pests, pathogens and vegetation: The role of weeds and wild plants in the ecology of crop pests and diseases. Pitman, London.

Weinzierl, R. 2002. Insect pest management for commercial vegetable crops, p. 149-181. In: 2002 Illinois agricultural pest management handbook. Univ. of Illinois Ext., Champaign.

Witkowski, J.F. and G.W. Echtenkamp. 1996. Influence of planting date and insecticide on the bean leaf beetle (Coleoptera:Chrysomelidae) abundance and damage in Nebraska soybean. J. Econ. Entomol. 89:189-196.

Zeiss, M.R. and L.P. Pedigo. 1996. Timing of food plant availability: Effect on survival and oviposition of the bean leaf beetle (Coleoptera: Chrysomelidae). Environ. Entomol. 25:295-302. 